\title{
Geographical Distribution of Four Sugarcane yellow leaf virus Genotypes
}

Youssef Abu Ahmad and Monique Royer, UMR Agro.M-CIRAD-INRA Biologie et Génétique des Interactions Plante-Parasite, Centre de Coopération Internationale en Recherche Agronomique pour le Développement (CIRAD), Campus International de Baillarguet, TA 41/K, 34398 Montpellier Cedex 5, France; Jean-Henrich Daugrois, UR Multiplication Végétative, CIRAD Département Cultures annuelles, Station de Roujol, 97170 Petit-Bourg, Guadeloupe, FWI; Laurent Costet and Jean-Michel Lett, UMR CIRAD-Université de La Réunion, Peuplements Végétaux et Bioagresseurs en Milieu Tropical, Ligne Paradis, 97410 Saint-Pierre, La Réunion; Jorge I. Victoria, CENICAÑA, Calle 58 Norte No. 3BN-110, Cali, Valle, Colombia; Jean-Claude Girard and Philippe Rott, UMR Agro.M-CIRAD-INRA Biologie et Génétique des Interactions Plante-Parasite, Centre de Coopération Internationale en Recherche Agronomique pour le Développement, Campus International de Baillarguet, TA 41/K, 34398 Montpellier Cedex 5, France

\begin{abstract}
Abu Ahmad, Y., Royer, M., Daugrois, J.-H., Costet, L., Lett, J.-M., Victoria, J. I., Girard, J.-C., and Rott, P. 2006. Geographical distribution of four Sugarcane yellow leaf virus genotypes. Plant Dis. 90:1156-1160.

Specific primer pairs were designed to distinguish four genotypes (BRA for Brazil, CUB for Cuba, PER for Peru, and REU for Réunion Island) of Sugarcane yellow leaf virus (SCYLV) by reverse transcription-polymerase chain reaction (RT-PCR). A unique genome fragment was amplified from each genotype, with the exception of genotypes BRA and PER that are phylogenetically relatively close and were designated genotype BRA-PER. These RT-PCR primers were then used to identify the SCYLV genotype(s) present in 18 different sugarcane growing locations in the world, and 245 leaf samples infected by the virus were analyzed. Most samples were infected by only one of the three genotypes, but mixed infections occurred. Genotype BRA-PER was found in all sugarcane growing locations, whereas genotypes CUB and REU were each found in four geographical locations only. Genotypes BRA-PER, CUB, and REU were all three detected in locally bred sugarcane cultivars in Guadeloupe, indicating local transmission of these genotypes. In contrast, only genotypes BRA-PER and CUB were found in locally bred cultivars in Brazil, whereas genotype REU was detected in this country in cultivar R570 imported from Réunion. Similarly, genotypes BRA-PER and REU are both present in Réunion, but genotype BRA-PER has not, as of yet, spread on this island. Presence of several SCYLV genotypes in Brazil, Colombia, Guadeloupe, Mauritius, and Réunion suggests different virus introductions and/or different evolution histories of the virus after its introduction into a new environment.
\end{abstract}

Additional keywords: Saccharum spp.

Sugarcane yellow leaf virus (SCYLV) is the causal agent of yellow leaf of sugarcane (Saccharum spp.), a disease previously called yellow leaf syndrome or YLS $(28,29)$. Yellow leaf was first reported in Hawaii and in Brazil in the late 1980s and early 1990s $(30,33)$, and it has since been reported in more than 30 sugarcane producing countries worldwide $(4,20)$. The incidence of SCYLV in commercial fields can reach $100 \%$ in susceptible cultivars $(6,7,25,34)$, and the disease can cause significant yield losses in susceptible cultivars even if infected plants do not exhibit overt disease symptoms $(8,15,27,33)$.

A characteristic symptom of the disease is an intense yellowing of the leaf midrib on the abaxial surface of mature leaves,

Corresponding author: P. Rott

E-mail: philippe.rott@ cirad.fr

Accepted for publication 20 April 2006.

DOI: 10.1094/PD-90-1156

(C) 2006 The American Phytopathological Society and this discoloration often occurs while the lamina is still green. In some sugarcane cultivars, leaves show a red coloration of the midrib on the adaxial surface. The leaf blade can then become bleached, proceeding from the tip toward the base of the leaf. Dwarfing of terminal internodes and tissue necrosis can also eventually be observed. Infected plants show a reduction of sucrose in stalks and an increase of sucrose accumulation in midribs $(10,13)$. Sometimes symptoms appear only when infected canes are stressed (17). However, most of these symptoms may be related to other biotic or abiotic factors such as stress conditions, insect damage, water logging, and cool winters $(5,20)$. The virus resides in the phloem tissue of plants and is transmitted during vegetative propagation of sugarcane by planting infected cuttings $(19,26$, 29,32). SCYLV is transmitted from plant to plant by the aphid vectors Melanaphis sacchari, Rhopalosiphum maidis, and $R$. rufiabdominalis in a persistent, circulative, and nonreplicative manner $(21,29,32)$.

SCYLV has recently been assigned to the genus Polerovirus of the family Luteo- viridae (9), and several genetic diversity studies showed that SCYLV is a variable virus $(1,2,22)$. Based on phylogenetic analyses of sequences of the entire translated genome of SCYLV, Abu Ahmad et al. (1) described the occurrence of three different genotypes (BRA, PER, and REU) within eight virus isolates from worldwide locations. The name given to each of these genotypes was based on the geographical location where it was first detected: Brazil, Peru, and Réunion, respectively. Sequence identity varied from 94.2 to $95.5 \%$ among isolates of genotypes BRA and REU, and from 93.9 to $94.1 \%$ among isolates of genotypes PER and REU. Although genotype PER isolates showed 96.7 to $98.5 \%$ sequence identity with genotype BRA isolates, genotype PER formed a separate lineage. Additionally, a virus isolate from Cuba that was partially sequenced showed only 77 to $80 \%$ amino acid sequence identity in open reading frame 1 (ORF1) with isolates of genotypes BRA, REU, and PER. This result suggested that the Cuban isolate represented another genotype or even an isolate of a new virus species (1). In the study herein, this virus isolate will be considered as another genotype of SCYLV and called CUB for Cuba.

The objective of our study was to analyze the distribution and incidence of SCYLV genotypes BRA, CUB, PER, and REU in different geographical locations in the world. We report here the design of specific primers to identify genotypes BRA (or PER), CUB, and REU by reverse transcription-polymerase chain reaction (RT-PCR), and the genotyping of SCYLV in 245 leaves infected by the virus and collected from 18 sugarcane growing locations from four continents (North and South America, Asia, and Africa).

\section{MATERIALS AND METHODS}

Infected plant material and RNA extraction. Leaves infected by SCYLV were collected from Cirad's sugarcane quarantine facility (3) or directly from diseased fields (Table 1). Tissue blot immunoassay (TBIA) and RT-PCR were used to verify the presence of SCYLV in leaf samples. TBIA was performed as described by 
Schenck et al. (31), except that Fast Blue BB salt (Sigma Chemical Co.) was used. RT-PCR with diagnostic primers YLS111 and YLS462 (1) and Ready-To-Go RTPCR Beads (Amersham) was performed as described by Comstock et al. (4). The amplified fragment from the coat protein coding sequence has an expected size of $351 \mathrm{bp}$ (fragment YLS, Fig. 1). Leaves were stored at $-80^{\circ} \mathrm{C}$ until RNA extraction. Total RNA was extracted and purified from sugarcane leaves $(100 \mathrm{mg}$ of lamina and midrib) with the RNeasy Plant Mini Kit (Qiagen) using the manufacturer's protocol. Total RNA was eluted in a final volume of $40 \mu \mathrm{l}$ of diethylpyrocarbonatetreated (DEPC) water and stored at $-20^{\circ} \mathrm{C}$.

SCYLV genome sequences and design of specific primer pairs for SCYLV genotyping. Sequences of the entire translated genome of 10 SCYLV isolates available in the GenBank data library (accession numbers AM072750, AM072751, AM072752, AM072753, AM072754, AM072755, AM072756, AF157029, AJ249447, AY236971) and sequences of an additional five SCYLV isolates (Y. Abu
Ahmad, M. Royer, and P. Rott, unpublished data) were used. Sequences were aligned and analyzed with DNAMAN Sequence Analysis Software (Lynnon BioSoft, Vaudreuil, Canada). A contiguous 5,609 to 5,612 bp (ATG ORF0 to stop codon ORF5) sequence was obtained for all 15 isolates. Genome regions that showed nucleotide variation among genotypes BRA, CUB, PER, and REU were used to design primers for RT-PCR amplification of a distinct fragment from each genotype. These primers were also tested in combination with nonselective primers that were previously described (1).

Amplification of a specific genome fragment from each SCYLV genotype by RT-PCR. A distinct fragment for each genotype was amplified by RT-PCR using the Titan One Tube RT-PCR System kit (Roche) and primer pairs that were located in different locations of the viral genome (Table 2 and Fig. 1). The same RNA template was used for all RT-PCR reactions performed with a given virus isolate. The 25- $\mu$ RT-PCR reaction mix consisted of 1 $\mu \mathrm{l}$ of eluted RNA, $5 \mu \mathrm{l}$ of RT-PCR buffer (5x), $1.25 \mu \mathrm{l}$ of DTT solution $(100 \mathrm{mM})$, $0.25 \mu \mathrm{l}$ of RNase inhibitor $\left(40 \mathrm{U} \mathrm{ul}^{-1}\right), 0.5$ $\mu \mathrm{l}$ of dNTP mix $(10 \mathrm{mM}), 0.5 \mu \mathrm{l}$ of Titan enzyme mix, $0.05 \mu \mathrm{l}$ of each primer $(100$ $\mu \mathrm{M})$, and DEPC water to final volume. The same RT-PCR program was used for all SCYLV genotypes: $56^{\circ} \mathrm{C}$ for $60 \mathrm{~min}$, $94^{\circ} \mathrm{C}$ for $2 \mathrm{~min}, 30$ cycles at $94^{\circ} \mathrm{C}$ for 15 $\mathrm{s}, 61^{\circ} \mathrm{C}$ for $2 \mathrm{~min}$, and $68^{\circ} \mathrm{C}$ for $2 \mathrm{~min}$ with a final $68^{\circ} \mathrm{C}$ extension for $10 \mathrm{~min}$. A $10-\mu l$ aliquot of each amplification product was analyzed through a $1.0 \%$ agarose gel by electrophoresis in TBE buffer, stained with ethidium bromide, and visualized under UV light. The amplification product of SCYLV genotypes BRA (or PER), CUB, and REU had expected sizes of 362,450 , and $905 \mathrm{bp}$, respectively (Table 2 and Fig. 2).

\section{RESULTS}

Selection of specific RT-PCR primers for identification of SCYLV genotypes. Several primer pairs were tested to distinguish SCYLV genotypes BRA, CUB, PER, and REU by selective amplification of a distinct genome fragment (data not

Table 1. Source of Sugarcane yellow leaf virus (SCYLV) infected leaves and identification of SCYLV genotypes in 245 samples from 18 different geographical locations

\begin{tabular}{|c|c|c|c|}
\hline Origin of sample & Sugarcane host cultivar (interspecific Saccharum hybrids) & SCYLV genotype & $\begin{array}{c}\text { Number } \\
\text { of samples }\end{array}$ \\
\hline Barbados & B85287, B86776, B9702, BT74209, BT7748, Co6806, DB8811, DB89138 & BRA-PER & 8 \\
\hline Brazil & $\begin{array}{l}\text { R570, RB80-6043, RB84-5257, RB85-5113, SP71-1406, SP71-6163, SP77-5181, } \\
\text { SP81-1763 }\end{array}$ & BRA-PER ${ }^{\mathrm{a}}$ & 15 \\
\hline Brazil & RB83-5054, SP71-6163, SP81-3250, SP83-5073 & BRA-PER + CUB & 4 \\
\hline Brazil & R570 & BRA-PER + REU & 2 \\
\hline China & $\begin{array}{l}\text { CGT73-167, CMT70-611, CP70-1133, CYT93-159, CYT85-1589, CYZ81-173, } \\
\text { FR93435, ROC3 }\end{array}$ & BRA-PER $^{\mathrm{a}}$ & 10 \\
\hline Colombia & $\begin{array}{l}\text { C1616-75, CC92-2227, CC92-2376, CC92-2885, Co421, CP38-34, Ja64-20, } \\
\text { PR77-3007, SP71-6163 }\end{array}$ & BRA-PER & 16 \\
\hline Colombia & $\begin{array}{l}\text { C1051-73, C236-51, C2655-74, CC84-75, CC85-96, CC87-505, CC92-2867, } \\
\text { CC92-2882, CC92-2885, CC93-3811, CP38-34, Mex64-1487, POJ2878 }\end{array}$ & CUB & 21 \\
\hline Colombia & CC85-96 & BRA-PER + CUB & 7 \\
\hline Cuba & Ja64-11 & BRA-PER & 1 \\
\hline Cuba & C132-81 & CUB & 4 \\
\hline Florida & CP85-1491, CP86-1633, CP89-2143, R570, TCP87-3388 & BRA-PER & 9 \\
\hline Guadeloupe & B37-161, CP67-412, FR9453, SP79-1169 & BRA-PER & 11 \\
\hline Guadeloupe & $\begin{array}{l}\text { B68409, FR9707, FR9976, FR99101, FR0020, FR0048, FR00102, FR00170, } \\
\text { SP71-6163 }\end{array}$ & CUB & 13 \\
\hline Guadeloupe & $\begin{array}{l}\text { CB56-171, FR90714, FR9707, FR9856, FR9979, FR9983, FR00306, R570, R578, } \\
\text { SP71-3146, SP71-6163 }\end{array}$ & REU & 32 \\
\hline Guadeloupe & FR99273, SP71-6163 & BRA-PER + REU & 2 \\
\hline Guadeloupe & FR9604, SP71-6163 & CUB + REU & 2 \\
\hline Hawaii & $\mathrm{R} 570$ & BRA-PER & 5 \\
\hline Malaysia & TC2, TC4 & BRA-PER & 2 \\
\hline Martinique & B7623, B7656, FR91180, FR91485, FR91816 & BRA-PER & 5 \\
\hline Mauritius & M124/59, M253/58 & BRA-PER & 2 \\
\hline Mauritius & M1186/86, M2024/88, R570, SP71-6163 & REU & 6 \\
\hline Mauritius & R570 & BRA-PER + REU & 3 \\
\hline Peru & H32-8560, H50-7209 & BRA-PER ${ }^{b}$ & 3 \\
\hline Philippines & VMC71-238, VMC76-16, VMC87-599 & BRA-PER & 3 \\
\hline Réunion Island & “SP71-6163”c & BRA-PER & 1 \\
\hline Réunion Island & R490, R570, R577, R84408 & REU & 30 \\
\hline Réunion Island & "SP71-6163"c & BRA-PER + REU & 15 \\
\hline Senegal & CP72-2086, CP85-1491, CP86-1664, NA6390 & BRA-PER & 5 \\
\hline Sri Lanka & SLC9225, SLC9272, SLC9273, SLC9294 & BRA-PER & 4 \\
\hline Sudan & KnB96207, KnB96223 & BRA-PER & 2 \\
\hline Taiwan & ROC6, ROC10 & BRA-PER & 2 \\
\hline
\end{tabular}

a Isolates from sugarcane cultivar SP71-6163 in Brazil and cultivar CGT63-167 in China belong to genotype BRA based on the phylogenetic study of the entire translated genome of SCYLV (1).

${ }^{b}$ Isolates from sugarcane cultivar H50-7209 belong to genotype PER based on the phylogenetic study of the entire translated genome of SCYLV (1).

${ }^{\mathrm{c}}$ Mislabeled cultivar. 


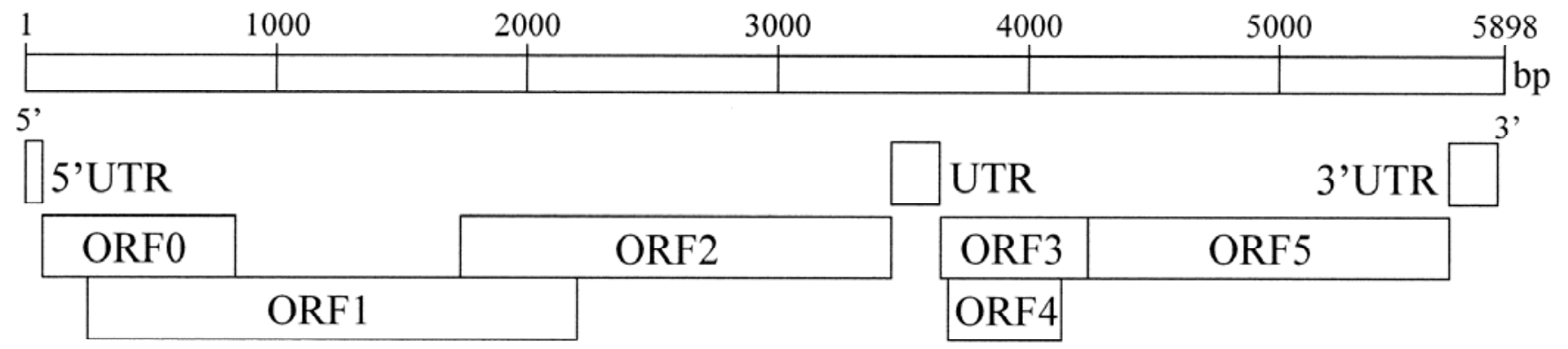

Fragment CUB

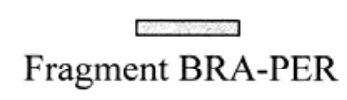

\section{Fragment YLS}

\section{Fragment REU}

Fig. 1. Genome organization of Sugarcane yellow leaf virus as described by Moonan et al. (23) and location of the fragments amplified by reverse transcription-polymerase chain reaction $(\mathrm{RT}-\mathrm{PCR})$. UTR $=$ untranslated region, $\mathrm{ORF}=$ open reading frame.

shown). Virus isolates representative of each genotype were used, and at least one specific primer pair was successfully identified per genotype to differentiate the four genotypes, with the exception of genotypes BRA and PER, which are phylogenetically relatively close (Table 2 ). The primer pair designed and chosen for amplification of genotype BRA isolates also amplified the two known isolates of genotype PER from Peru. Genotype BRA-PER will therefore be used below to designate this group of two closely related genotypes.

Genotyping of SCYLV in 18 sugarcane growing locations. The SCYLV genotype(s) occurring in 245 infected leaf samples from 18 different sugarcane growing locations in the world was determined by RT-PCR amplification with three different primer pairs (Tables 1 and 2). Genotypes BRA-PER, CUB, and REU were found in $137(56 \%), 51(21 \%)$, and 82 (33\%) of the 245 samples, respectively. Mixed infections of genotypes BRA-PER + REU, BRA-PER + CUB, and CUB + REU were detected in $22(9 \%), 11(4 \%)$, and $2(1 \%)$ of the 245 samples, respectively (Fig. 2).

At least one leaf sample from each of the 18 investigated geographic locations was infected by genotype BRA-PER (Table 1). BRA-PER was the only genotype found in Barbados, China, Florida, Hawaii, Malaysia, Martinique, Peru, Philippines, Senegal, Sri Lanka, Sudan, and Taiwan. Genotype CUB was found only in Brazil (in 4 of 21 samples), Colombia (in 28 of 44 samples), Cuba (in 4 of 5 samples), and Guadeloupe (in 15 of 60 samples). Genotype REU was found only in Brazil (in 2 of 21 samples), Guadeloupe (36 of 60 samples), Mauritius (9 of 11 samples), and Réunion Island (45 of 46 samples).

Table 2. Sequence and position in the Sugarcane yellow leaf virus (SCYLV) genome of the primers used for genotype identification by RT-PCR

\begin{tabular}{llcl}
\hline Amplified fragment $^{\mathbf{a}}$ & $\begin{array}{l}\text { Name of } \\
\text { primers }\end{array}$ & $\begin{array}{c}\text { Genome } \\
\text { position }^{\mathbf{b}}\end{array}$ & $\mathbf{5 \bullet - 3 \bullet \text { sequence } ^ { \mathbf { c } }}$ \\
\hline BRA-PER & BRA-PER-F & $1,905-1,924$ & AACTGCTGCgtcAgGCcCa \\
& BRA-PER-R & $2,267-2,246$ & GACGAGCtTGCGTTGTtttCt \\
CUB & CUB-F & $423-443$ & gTGCttcTCCcgGCGGTTcact \\
& CUB-R & $873-853$ & attcGaGAACAACCTcCgcctc \\
REU & REU-F & $3,540-3,558$ & CAAgCTCTAGCgGaTc \\
& B-REV & $4,445-4,427$ & CAGTTGCTCaATGCTCCAcG \\
\hline
\end{tabular}

a See genome location in Figure 1.

${ }^{b}$ Position in the SCYLV complete genome (GenBank accession no. AF157029).

${ }^{c}$ Polymorphic nucleotides are written in lower case.

d Primer previously described by Abu Ahmad et al. (1).

Locally bred varieties were all infected by genotype BRA-PER in Brazil (15 samples) and by genotype REU in Réunion Island (30 samples) (Table 3). Two to three genotypes were found in locally bred varieties in Colombia (BRA-PER and CUB), Guadeloupe (BRA-PER, CUB, and REU), and Mauritius (BRA-PER and REU). SCYLV genotype CUB showed the highest incidence in locally bred varieties in Colombia where 22 of 26 samples (84\%) were infected by this genotype. In Guadeloupe, genotype REU was the most common, and 18 of 29 samples (62\%) collected from locally bred varieties were infected by this genotype.

\section{DISCUSSION}

These three genotypes of SCYLV are not distributed uniformly in the world. Genotype BRA-PER was found in 18 sugarcane growing locations in Africa, Asia, and North, Central, and South America, whereas genotypes CUB and REU were found in only four locations each. World distribution of genotype BRA-PER suggests that yellow leaf was originally caused by this genotype, which was spread worldwide by infected plant material when the causal agent of yellow leaf was unknown and not intercepted in sugarcane quarantines (3). Although genotype BRAPER is present all around the world, its incidence varied according to the sugarcane growing location. It was found in all sampled sugarcane varieties in Barbados, Brazil, China, and Florida; but in Réunion Island, it was only detected in an imported foreign variety. This latter variety was initially thought to be SP71-6163, the variety severely affected by yellow leaf in Brazil (20,33), but recent genomic fingerprinting showed that this variety was mislabeled (J. Pauquet, personal communication). Several reasons may explain the absence of spread of genotype BRA-PER in Réunion Island. This SCYLV genotype may have only recently been imported to this location highly contaminated by $\operatorname{SCYLV}(25,27)$, and has not been significantly spread yet because of limited inoculum sources. It can also be hypothesized that insect vectors present in Réunion Island do not efficiently spread genotype BRA-PER or that the local environment is not favorable to genotype BRA-PER. A 


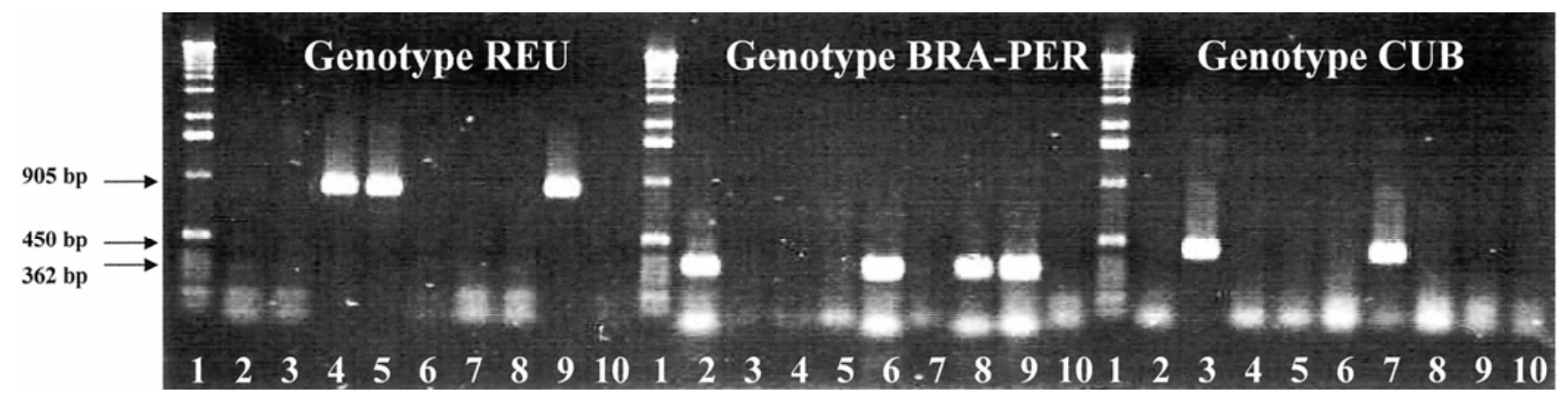

Fig. 2. Reverse transcription-polymerase chain reaction (RT-PCR) amplification products of three genotypes of Sugarcane yellow leaf virus (SCYLV) with genotype-specific primers. Lanes: 1 = ladder $(1 \mathrm{~kb}) ; 2$ to $9=$ sugarcane leaf samples infected by SCYLV isolates PER-YL1 from Peru, CUB-YL1 from Cuba, REU-YL1 from Réunion, REU-YL2 from Réunion, BRA-YL1 from Brazil, COL-YL1 from Colombia, CHN-YL1 from China, REU-YL3 from Réunion, respectively; and 10 = virus-free sugarcane leaf sample. Each virus isolate was a single genotype with the exception of REU-YL3, which was a mixed infection (genotypes REU + BRA-PER).

Table 3. Genotypes of Sugarcane yellow leaf virus (SCYLV) in locally bred and imported varieties in five sugarcane growing locations

\begin{tabular}{|c|c|c|c|c|c|c|c|c|c|}
\hline \multirow[b]{2}{*}{ Location } & \multirow[b]{2}{*}{$\begin{array}{l}\text { Variety type (total } \\
\text { number of varieties) }\end{array}$} & \multicolumn{6}{|c|}{ Number of samples infected by SCYLV genotype(s) } & \multirow{2}{*}{\multicolumn{2}{|c|}{$\begin{array}{c}\text { Total } \\
\text { number of } \\
\text { samples }\end{array}$}} \\
\hline & & BRA-PER & CUB & REU & $\begin{array}{l}\text { BRA-PER } \\
\text { + CUB }\end{array}$ & $\begin{array}{l}\text { BRA-PER } \\
\text { + REU }\end{array}$ & $\begin{array}{l}\text { REU } \\
+ \text { CUB }\end{array}$ & & \\
\hline \multirow[t]{2}{*}{ Brazil } & Locally bred RB and SP (10) & 11 & 0 & 0 & 4 & 0 & 0 & 15 & \\
\hline & Imported varieties (1) & 4 & 0 & 0 & 0 & 2 & 0 & 6 & 21 \\
\hline \multirow[t]{2}{*}{ Colombia } & Locally bred CC (9) & 4 & 15 & 0 & 7 & 0 & 0 & 26 & \\
\hline & Imported varieties (11) & 12 & 6 & 0 & 0 & 0 & 0 & 18 & 44 \\
\hline \multirow[t]{2}{*}{ Guadeloupe } & Locally bred FR (16) & 3 & 8 & 14 & 0 & 2 & 2 & 29 & \\
\hline & Imported varieties (12) & 8 & 5 & 18 & 0 & 0 & 0 & 31 & 60 \\
\hline \multirow[t]{2}{*}{ Mauritius } & Locally bred M (4) & 2 & 0 & 2 & 0 & 0 & 0 & 4 & \\
\hline & Imported varieties (2) & 0 & 0 & 4 & 0 & 3 & 0 & 7 & 11 \\
\hline \multirow{2}{*}{ Réunion Island } & Locally bred R (4) & 0 & 0 & 30 & 0 & 0 & 0 & 30 & \\
\hline & Imported varieties (1) & 1 & 0 & 0 & 0 & 15 & 0 & 16 & 46 \\
\hline
\end{tabular}

similar situation occurs in Brazil where genotype REU was detected in variety R570 imported from Réunion Island, but not in locally bred varieties. Strain-specific transmission has been reported for other viruses of the Luteoviridae family such as Barley yellow dwarf virus (BYDV) $(12,14,24,35)$ and Potato leafroll virus (PLRV) (18). In contrast, in Colombia and Guadeloupe, two (BRA-PER and CUB) and three (BRA-PER, CUB, and REU) genotypes were detected in locally bred sugarcane varieties, respectively, which proved local transmission of all these genotypes because no diseases are known to be transmitted through the caryopsis of the sugarcane fruit (11). Local transmission of SCYLV genotypes BRA-PER, CUB, and REU in Guadeloupe was also demonstrated by the detection of these genotypes in sugarcane fields several months after planting of healthy tissuecultured plants (data not shown). Several genotypes of SCYLV can therefore coexist in a geographical location, but also in a sugarcane plant as demonstrated by the detection of mixed genotype infections in a few samples.

Genotype CUB was only found in South America (Brazil, Colombia, and Cuba) and in Guadeloupe. Genotype REU was only found in locally bred varieties in Guadeloupe, Mauritius, and Réunion Island. The limited geographical distribution of these two genotypes might be due to specific pathogen $\times$ host $\times$ vector $\times$ environment interactions, and therefore different evolution histories. Future surveys and genotyping studies in the geographical locations sampled in this study should supply useful data regarding evolution of SCYLV populations.

Because Saccharum species (including traditional and modern sugarcane cultivars and wild relatives) are the only known natural hosts of $\operatorname{SCYLV}(19,20,32)$, and because these species (with the exception of some $S$. spontaneum clones in part of Africa) are not native to the Americas, Africa, or the Mascareines Archipelago (16), SCYLV was imported into these locations from elsewhere via infected planting material. The presence of several genotypes of SCYLV in Brazil, Colombia, Guadeloupe, Mauritius, and Réunion Island suggests different virus introductions. Additionally, other genotypes of SCYLV not yet described may occur in the world, especially in traditional sugarcane cultivars (S. officinarum, S. barberi, S. sinense) and wild relatives ( $S$. spontaneum and $S$. robustum) not tested in this study, and the biological significance of this genetic diversity remains to be determined.

\section{ACKNOWLEDGMENTS}

We thank our colleagues from Barbados (WICSCBS), Brazil (COPERSUCAR and UFSCAR), China (YSRI), Cuba (INICA), Florida (USDA), Hawaii (HARC), Malaysia (KGFPSB), Martinique (CTCS), Mauritius (MSIRI), Peru
(AIPSA), Philippines (PHILSURIN), Senegal (CSS), Sri Lanka (SRI), Sudan (KSC Ltd), and Taiwan (TSRI) for supplying sugarcane samples infected by SCYLV. We also thank Jean-François Bousquet, Marc Muller, and Rémy Habas for collecting SCYLV infected samples in the sugarcane quarantine of CIRAD, Marie-Josée Darroussat and Emmanuel Fernandez for technical assistance, and Erik Mirkov for critical reviewing of the manuscript. This research was conducted during the thesis scholarship program of Y. Abu Ahmad, supported by the Government of Syrian Arabic Republic.

\section{LITERATURE CITED}

1. Abu Ahmad, Y., Rassaby, L., Royer, M., Borg, Z., Braithwaite, K. S., Mirkov, E., Irey, M. S., Perrier, X., Smith, G. R., and Rott, P. 2006. Yellow leaf of sugarcane is caused by at least three different genotypes of sugarcane yellow leaf virus, one of which predominates on the Island of Réunion. Arch. Virol. Online, publication DOI 10.1007/s00705-005-0712-9.

2. Borg, Z., Moonan, F., Braithwaite, K., Mirkov, T. E., and Smith, G. 2001. Characterising the genetic diversity of Sugarcane yellow leaf virus. Proc. Int. Soc. Sugar Cane Technol. Congr. 24:654-656.

3. Chatenet, M., Delage, C., Ripolles, M., Irey, M., Lockhart, B. E. L., and Rott, P. 2001. Detection of Sugarcane yellow leaf virus in quarantine and production of virus-free sugarcane by apical meristem culture. Plant Dis. 85:11771180 .

4. Comstock, J. C., Irey, M. S., Lockhart, B. E. L., and Wang, Z. K. 1998. Incidence of yellow leaf syndrome in CP cultivars based on polymerase chain reaction and serological techniques. Sugar Cane 4:21-24.

5. Comstock, J. C., Irvine, J. E., and Miller, J. D. 1994. Yellow leaf syndrome appears on the United States mainland. Sugar J. 56:33-35.

6. Comstock, J. C., Miller, J. D., and Schnell, R. 
J. 2001. Incidence of Sugarcane yellow leaf virus in clones maintained in the world collection of sugarcane and related grasses at the United States National Repository in Miami, Florida. Sugar Tech 3(4):128-133.

7. Comstock, J. C., Miller, J. D., Tai, P. Y. P., and Follis, J. E. 1999. Incidence of and resistance to sugarcane yellow leaf virus in Florida. Proc. Int. Soc. Sugar Cane Technol. Congr. 23:366372 .

8. Cronjé, C. P. R., Tymon, A. M., Jones, P., and Bailey, R. A. 1998. Association of a phytoplasma with a yellow leaf syndrome of sugarcane in Africa. Ann. Appl. Biol. 133:177-186.

9. D'Arcy, C. J., and Domier, L. L. 2005. Luteoviridae. Pages 891-900 in: Virus Taxonomy. VIIIth Report of the International Committee on Taxonomy of Viruses. C. M. Fauquet, M. A. Mayo, J. Maniloff, U. Desselberger, and L. A. Ball, eds. Academic Press, New York.

10. Fontaniella, B., Vicente, C., Legaz, E. M., Armas, R., Rodriguez, C. W., Martinez, M., Piñón, D., Acevedo, R., and Solas, M. T. 2003. Yellow leaf syndrome modifies the composition of sugarcane juices in polysaccharides, phenols and polyamines. Plant Physiol. Biochem. 41:1027-1036.

11. Frison, E. A., and Putter, C. A. J. 1993. FAO/IBPGR Technical guidelines for the safe movement of sugarcane germplasm. Food and Agriculture Organization of the United Nations/International Board for Plant Genetic Resources, Rome, Italy.

12. Gildow, F. E., and Gray, S. M. 1993. The aphid salivary gland basal lamina as a selective barrier associated with vector-specific transmission of barley yellow dwarf luteovirus. Phytopathology 83:1293-1302.

13. Gonçalves, C. M., Vega, J., Olivieira, G. J., and Gomes, M. A. M. 2005. Sugarcane yellow leaf virus infection leads to alterations in photosynthetic efficiency and carbohydrate accumulation in sugarcane leaves. Fitopatol. Bras. 30:10-16.

14. Gray, S., and Gildow, F. E. 2003. Luteovirusaphids interaction. Annu. Rev. Phytopathol. 41:539-599.

15. Grisham, M. P., Pan, Y. B., White, W. H., Godshall, M. A., Legendre, B. L., and Comstock, J. C. 2002. Potential effect of yellow leaf syndrome on the Louisiana sugarcane industry. J. Am. Soc. Sugar Cane Technol. 22:125-126.
16. Grivet, L., Daniels, C., Glaszmann, J.-C., and D'Hont, A. 2004. A review of recent molecular genetics evidence for sugarcane evolution and domestication. Ethnobotany Res. Appl. 2:9-17.

17. Izaguirre-Mayoral, M. L., Carballo, O., Alceste, C., Romano, M., and Nass, H. A. 2002. Physiological performance of asymptomatic and yellow leaf syndrome-affected sugarcanes in Venezuela. J. Phytopathol. 150:13-19.

18. Jolly, C. A., and Mayo, M. A. 1994. Changes in the amino acid sequences of the coat protein read through domain of Potato leafroll luteovirus affect the formation of an epitope and aphid transmission. Virology 201:182-185.

19. Lehrer, A. T., Schenck, S., Fitch, M. M. M., Moore, P. H., and Komor, E. 2001. Distribution and transmission of Sugarcane yellow leaf virus (SCYLV) in Hawaii and its elimination from seedcane. Proc. Int. Soc. Sugar Cane Technol. Congr. 24:439-443.

20. Lockhart, B. E. L., and Cronjé, C. P. R. 2000. Yellow leaf syndrome. Pages 291-295 in: A Guide to Sugarcane Diseases. P. Rott, R. A. Bailey, J. C. Comstock, B. J. Croft, and A. S. Saumtally, eds. La Librairie du Cirad, Montpellier.

21. Lockhart, B. E. L., Irey, M. S., and Comstock, J. C. 1996. Sugarcane baciliform virus, sugarcane mild mosaic virus and sugarcane yellow leaf syndrome. Page 108-112 in: Sugarcane Germplasm Conservation and Exchange, ACIAR Proc. No 67. B. J. Croft, C. M. Piggin, E. S. Wallis, and D. M. Hogarth, eds. Australian Centre for International Agricultural Research, Canberra.

22. Moonan, F., and Mirkov, T. E. 2002. Analyses of the genotypic diversity among North, South, and Central American isolates of Sugarcane yellow leaf virus. Evidence for Colombian origins and for intraspecific spatial phylogenetic variation. J. Virol. 76:1339-1348.

23. Moonan, F., Molina, J., and Mirkov, T. E. 2000. Sugarcane yellow leaf virus: An emerging virus that has evolved by recombination between luteoviral and poleroviral ancestors. Virology 269:156-171.

24. Peiffer, M. L., Gildow, F. E., and Gray, S. M. 1997. Two distinct mechanisms regulate luteovirus transmission efficiency and specificity at the aphid salivary gland. J. Gen. Virol. 78:495503.

25. Rassaby, L., Girard, J. C., Irey, M. S., Lockhart, B. E. L., Kodja, H., and Rott, P. 2001.
Yellow leaf syndrome in sugarcane cultivars of Réunion Island: Dynamics of SCYLV in the field and in the plant. Proc. Int. Soc. Sugar Cane Technol. Congr. 24:451-455.

26. Rassaby, L., Girard, J. C., Lemaire, O., Costet, L., Irey, M. S., Kodja, H., Lockhart, B. E. L., and Rott, P. 2004. Spread of Sugarcane yellow leaf virus in sugarcane plants and fields on the Island of Réunion. Plant Pathol. 53:117-125.

27. Rassaby, L., Girard, J.-C., Letourmy, P. Chaume, J., Irey, M. S., Lockhart, B. E. L., Kodja, H., and Rott, P. 2003. Impact of Sugarcane yellow leaf virus on sugarcane yield and juice quality in Réunion Island. Eur. J. Plant Pathol. 109:459-466.

28. Rott, P., Comstock, J. C., Croft, B. J., Kusalwong, A., and Saumtally, S. 2005. Advances and challenges in sugarcane pathology: A review of the 2003 pathology workshop. Proc. Int. Soc. Sugar Cane Technol. Congr. 25:607614.

29. Scagliusi, S. M., and Lockhart, B. E. L. 2000 Transmission, characterization, and serology of a luteovirus associated with yellow leaf syndrome of sugarcane. Phytopathology 90:120-124.

30. Schenck, S. 2001. Sugarcane yellow leaf syndrome: History and current concepts. Pages 25-35 in: Sugarcane Pathology, Vol. II: Virus and Phytoplasma Diseases. G. P. Rao, R. E. Ford, M. Tosic, and D. S. Teakle, eds. Science Publishers Inc., Enfield, NH.

31. Schenck, S., Hu, J. S., and Lockhart, B. E. L. 1997. Use of a tissue blot immunoassay to determine the distribution of Sugarcane yellow leaf virus in Hawaii. Sugar Cane 4:5-8.

32. Schenck, S., and Lehrer, A. T. 2000. Factors affecting the transmission and spread of Sugarcane yellow leaf virus. Plant Dis. 84:10851088

33. Vega, J., Scagliusi, S. M. M., and Ulian, E. C. 1997. Sugarcane yellow leaf disease in Brazil: Evidence of association with a luteovirus. Plant Dis. 81:21-26.

34. Viswanathan, R. 2002. Sugarcane yellow leaf syndrome in India: Incidence and effect on yield parameters. Sugar Cane Intern. 5:17-23.

35. Zavaleta, E. L., Smith, D. M., and Gray, S. M. 2001. Variation in transmission efficiency among Barley yellow dwarf virus-RMV isolates and clones of the normally inefficient aphid vector, Rhopalosiphum padi. Phytopathology 91:792-796. 